\section{Seasonal Nitrogen Partitioning and Nitrogen Uptake of Carrots as Affected by Nitrogen Application in a Mineral and an Organic Soil}

\author{
Sean M. Westerveld, Alan W. McKeown, and Mary Ruth McDonald ${ }^{\mathbf{1}}$ \\ Department of Plant Agriculture, University of Guelph, Guelph, Ontario, \\ N1G 2W1 Canada
}

Additional index words. nitrogen removal, organic soil, mineral soil, nitrogen budget, Daucus carota

\begin{abstract}
An understanding of nitrogen (N) uptake and the partitioning of $\mathbf{N}$ during the season by the carrot crop (Daucus carota subsp. sativus [Hoffm.] Arkang.) is required to develop more efficient $\mathbf{N}$ fertilization practices. Experiments were conducted on both organic and mineral soils to track the accumulation of dry matter (DM) and $N$ over the growing season and to develop an $\mathbf{N}$ budget of the crop. Treatments included two carrot cultivars ('Idaho' and 'Fontana') and $5 \mathrm{~N}$ rates ranging from $0 \%$ to $200 \%$ of the provincial recommendations in Ontario. Foliage and root samples were collected biweekly from selected treatments during the growing season and assessed for total $N$ concentration. Harvest samples were used to calculate $N$ uptake, $N$ in debris, and net $N$ removal values. Accumulation of $D M$ and $N$ in the roots was low until 50 to 60 days after seeding (DAS) and then increased linearly until harvest for all 3 years regardless of the soil type, cultivar, and $\mathrm{N}$ rate. Foliage dry weight and $\mathrm{N}$ accumulation were more significant by 50 to 60 DAS, increased linearly between 50 and 100 DAS, and reached a maximum or declined slightly beyond $100 \mathrm{DAS}$ in most cases. The $\mathrm{N}$ application rates required to maximize yield on mineral soil resulted in a net loss of $\mathrm{N}$ from the system, except when sufficient $N$ was available from the soil to produce optimal yield. On organic soil, a net removal of $\mathrm{N}$ occurred at all $\mathrm{N}$ application rates in all years. Carrots could be used as an $\mathbf{N}$ catch crop to reduce $\mathbf{N}$ losses in a vegetable rotation in conditions of high soil residual $N$, thereby improving the $N$ use efficiency (NUE) of the crop rotation.
\end{abstract}

Knowledge of the patterns of uptake and partitioning of nitrogen $(\mathrm{N})$ and the production and partitioning of dry matter (DM) in the carrot (Daucus carota) crop over the growing season could be useful in identifying periods of peak $\mathrm{N}$ uptake and in adjusting fertilization practices accordingly. Carrots are known to begin forming the storage root between 13 and 34 days after seeding (DAS) (Esau, 1940; Hole et al., 1987a; Hole and Dearman, 1991). Between 34 and 65 DAS, there is a slow increase in foliage and root DM (Hole et al., 1983). This is followed by a rapid linear increase in root dry weight from

Received for publication 19 Jan. 2006. Accepted for publication $12 \mathrm{Apr}$. 2006. This paper is a portion of a PhD thesis submitted by Sean M. Westerveld. Funding provided by the Agricultural Adaptation Council through the support of the Ontario Fruit and Vegetable Grower's Association and the Natural Sciences and Engineering Research Council of Canada. We thank Kevin Vander Kooi, Marilyn Hovius, and the staff of the Muck Crops Research Station for their assistance. We also thank John Lauzon and Tiequan Zhang for reviewing the manuscript. We also thank Greg Patterson and A\&L Canada Laboratories, Inc. (London, Ontario) for providing tissue analyses.

${ }^{1}$ To whom correspondence should be addressed; e-mailmrmcdona@uoguelph.ca.
An $\mathrm{N}$ budget of the carrot crop could be used to determine the potential use of carrots in a rotation as an $\mathrm{N}$ catch crop and would assist in the development of nutrient management strategies. Nitrogen catch crops are crops used for the purpose of removing excess nutrients from the soil (Fream, 1905). No studies have examined the potential use of a rotation crop as an $\mathrm{N}$ catch crop. However, studies suggest that leaching of nitrate- $\mathrm{N}$ over the winter may be low in Ontario because soils are frozen for up to 4 months of the year (Ryan et al., 2000) and nitrate- $\mathrm{N}$ may accumulate lower in the soil profile where it could still be accessed by deeprooted crops in the next season (Sheppard and Bates, 1986). Carrots have been shown to exhibit deep rooting in Ontario (Westerveld, 2005) and Denmark (Thorup-Kristensen and van den Boogaard, 1999), and therefore, may be able to capture $\mathrm{N}$ that accumulates lower in the soil profile. In addition, crop $\mathrm{N}$ removal in the storage root of up to $130 \mathrm{~kg} \cdot \mathrm{ha}^{-1}$ is reported in Ontario, although the plants did not require supplemental $\mathrm{N}$ fertilization to produce maximal yield (Westerveld, 2002).

A better understanding of $\mathrm{N}$ partitioning over the season and of $\mathrm{N}$ accumulation in foliage and roots at harvest and how these are affected by soil type, cultivar, and $\mathrm{N}$ application is required. This will allow for an assessment of the potential use of carrots as an $\mathrm{N}$ catch crop and identification of more efficient fertilization practices. The purpose of this experiment was to identify the effects of cultivar, soil type, and $\mathrm{N}$ application rate on $\mathrm{DM}$ and $\mathrm{N}$ partitioning between the foliage and roots over the growing season and to develop an $\mathrm{N}$ budget of the carrot crop.

\section{Materials and Methods}

DAS until harvest (Platenius, 1934; Reid and English, 2000; Rubatzky et al., 1999; Strandberg, 2001) and a linear increase in foliage DM beginning slightly earlier and reaching a plateau or declining beyond 100 DAS (Platenius, 1934; Rubatzky et al., 1999). Nitrogen accumulation in the carrot plant is slow over the first 30 DAS and then increases rapidly until harvest (Salo, 1999).

No studies have examined how the dynamics of $\mathrm{N}$ uptake and partitioning over the growing season or the development of an $\mathrm{N}$ budget at harvest are affected by $\mathrm{N}$ application rate, cultivar, and soil type. This information would be useful in identifying the periods of peak $\mathrm{N}$ uptake and explaining how uptake patterns change depending on $\mathrm{N}$ availability. Strategies to improve the $\mathrm{N}$ use efficiency (NUE) of the carrot crop and the crop rotation could then be developed to reduce $\mathrm{N}$ losses and help growers cope with strict environmental laws, including the $\mathrm{Nu}$ trient Management Act in Ontario. Although carrots often do not require $\mathrm{N}$ fertilization to produce maximal yield in temperate regions (Evers, 1988; Sanderson and Ivany, 1997; Warncke, 1996; Westerveld, 2002), N application is required to keep Alternaria (A. dauci) and Cercospora (C. carotae) leaf blight damage at a minimum (Westerveld, 2005).
Experiments were conducted on a mineral and an organic soil on the Holland/Bradford


at or near the University of Guelph, Muck Crops Research Station from 2002 to 2004. The organic soil, a Hemic Histosol, contained $58 \%$ to $76 \%$ organic matter and had a $\mathrm{pH}$ of 6.1 to 6.8 . The mineral soil, a Typic Haplaquoll, contained $1.0 \%$ to $3.5 \%$ organic matter, $90 \%$ sand, and had a $\mathrm{pH}$ of 7.9 to 8.4 . Before the start of the experiment, field $\mathrm{N}$ concentrations in the top $30 \mathrm{~cm}$ of soil were and $2.4 \%$ total $\mathrm{N}$ for the organic soil plot and $2.4 \mathrm{mg} \cdot \mathrm{kg}^{-1} \mathrm{NH}_{4}-\mathrm{N}, 2.3 \mathrm{mg} \cdot \mathrm{kg}^{-1} \mathrm{NO}_{3}-\mathrm{N}$, and $0.09 \%$ total $\mathrm{N}$ for the mineral soil plot (Westerveld, 2005). Phosphorus (P) and potassium (K) fertilizer application was based on soil test results. The initial soil test results before 2002 were $87 \mathrm{mg} \cdot \mathrm{L}^{-1} \mathrm{P}$ and $160 \mathrm{mg} \cdot \mathrm{L}^{-1} \mathrm{~K}$ for the organic soil site and $81 \mathrm{mg} \cdot \mathrm{L}^{-1} \mathrm{P}$ and $112 \mathrm{mg} \cdot \mathrm{L}^{-1} \mathrm{~K}$ for the mineral soil site.

The experiments were arranged in a splitblock design with cultivar as the main plot and $\mathrm{N}$ rate as the subplot with 4 replications. Each experimental unit in the organic soil site in 2002 consisted of 8 beds ( 4 beds/cultivar), $5 \mathrm{~m}$ in length, $20 \mathrm{~cm}$ high, spaced $86 \mathrm{~cm}$ apart, and a seeding rate of $80 \mathrm{seeds} / \mathrm{m}$ of bed. $24.4 \mathrm{mg} \cdot \mathrm{kg}^{-1} \mathrm{NH}_{4}-\mathrm{N}, 89.1 \mathrm{mg} \cdot \mathrm{kg}^{-1} \mathrm{NO}_{3}-\mathrm{N}$, 
Each experimental unit in the mineral soil plot in 2002 consisted of 16 beds ( 8 beds/cultivar), $10 \mathrm{~m}$ in length, $20 \mathrm{~cm}$ high, spaced $86 \mathrm{~cm}$ apart, and a seeding rate of $80 \mathrm{seeds} / \mathrm{m}$ of bed. There were 3 rows spaced $5 \mathrm{~cm}$ apart on each bed. Each experimental unit was split in half in 2003 and 2004 for a purpose unrelated to this study, and all assessments were conducted on the same half in 2003 and 2004. Mineral soil plots were rehilled twice during the season in all 3 years. Nitrogen was applied at $0 \%, 50 \%, 100 \%, 150 \%$, and $200 \%$ of the Ontario recommended $\mathrm{N}$ rates (OMAF, 2002) to the entire experimental unit in 2002 and the half in which all assessments were made in 2003 and 2004 using ammonium nitrate. The recommendations were $60 \mathrm{~kg} \cdot \mathrm{ha}^{-1} \mathrm{~N}$ applied preplant on organic soil and $110 \mathrm{~kg} \cdot \mathrm{ha}^{-1} \mathrm{~N}$ split $66 \%$ preplant and $33 \%$ sidedress on mineral soil. Carrots were grown on the same site for 3 years in an attempt to induce a yield response to $\mathrm{N}$ application rate and identify minimum $\mathrm{N}$ requirements, but the lack of rotation is not recommended in Ontario.

Cultivars 'Idaho' and 'Fontana' were used in all field experiments. The cultivars were chosen because they represent a fresh market ('Idaho') and a processing ('Fontana') cultivar. Carrots were seeded using a Stan Hay precision seeder (Stan Hay Co., Ashford, U.K.) into the organic soil on 24 May 2002, 2 June 2003, and 21 May 2004, and into the mineral soil on 3 June 2002, 2 June 2003, and 20 May 2004.

Beginning when the plants were large enough to collect samples (foliage $15 \mathrm{~cm}$ high; roots $>0.5 \mathrm{~cm}$ diameter) in mid-July, samples were collected from 3 replications biweekly until 2 weeks before harvest in 2003 and 2004. Plant samples consisted of foliage and roots of 6 plants ( 10 plants for early sampling dates on mineral soil) taken from 2 separate locations within the middle 2 beds of each cultivar. Fibrous or deep taproots were not collected. Samples were collected from the no $\mathrm{N}$ and recommended $\mathrm{N}$ rate treatments on all 6 sampling dates in 2003 and 2004 for 'Idaho' and at the first (first and second in 2003) and fourth sampling dates for 'Fontana'. At harvest in 2002, samples were collected of both cultivars from the recommended rate treatment only. In 2003, samples were collected from 3 replications of the treatments at $0 \%, 100 \%$, and $200 \%$ of the recommended $\mathrm{N}$ rate. In 2004, samples were collected from all rates, replications, cultivars, and soil types. All samples were dried at $70{ }^{\circ} \mathrm{C}$ for 48 hours, weighed, and sent to the University of Guelph, Soil and Nutrient Laboratory (2002 and 2003) and A\&L Canada Laboratories Inc. (2003 and 2004) for total $\mathrm{N}$ analysis. Total $\mathrm{N}$ concentration was determined by automated dry combustion procedures by both laboratories (Shepers et al., 1989). The amount of N supplied in rainfall was estimated to be $8 \mathrm{~kg} \cdot \mathrm{ha}^{-1}$ per season based on $\mathrm{NO}_{3}-\mathrm{N}$ assessments of rainfall throughout the season in a previous study (Westerveld, 2002). Rainfall over the growing season in the previous study was $319 \mathrm{~mm} / \mathrm{season}$, which was comparable to 289 to $374 \mathrm{~mm} / \mathrm{season}$ in this study.

Results were converted to a per-hectare basis by factoring in yield and stand at harvest. For this assessment, carrots were hand-harvested from one (organic 2003 and 2004) and 2 (organic 2002 and mineral all 3 years) $2.3-\mathrm{m}$ sections of the middle beds of each cultivar and treatment on 18 Oct. 2002 , 27 and 28 Oct. 2003, and 21 Oct. 2004, on the organic soil and 24 Oct. 2002, 23 and 24 Oct. 2003, and 26 Oct. 2004 on the mineral soil. Results were calculated on a per-hectare basis to allow for comparison with previous research and to give an indication of the potential for $\mathrm{N}$ losses.

An analysis of variance was performed to partition the variance into treatment, block, and cultivar effects and to identify interactions among these effects. Data were not pooled by soil type or year because of the potential for residual effects from year to year and to highlight the differences between soil types. The entire data set for each assessment was assessed for normality using the ShapiroWilk test of residuals. Outliers were identified using Lund's test of standardized residuals
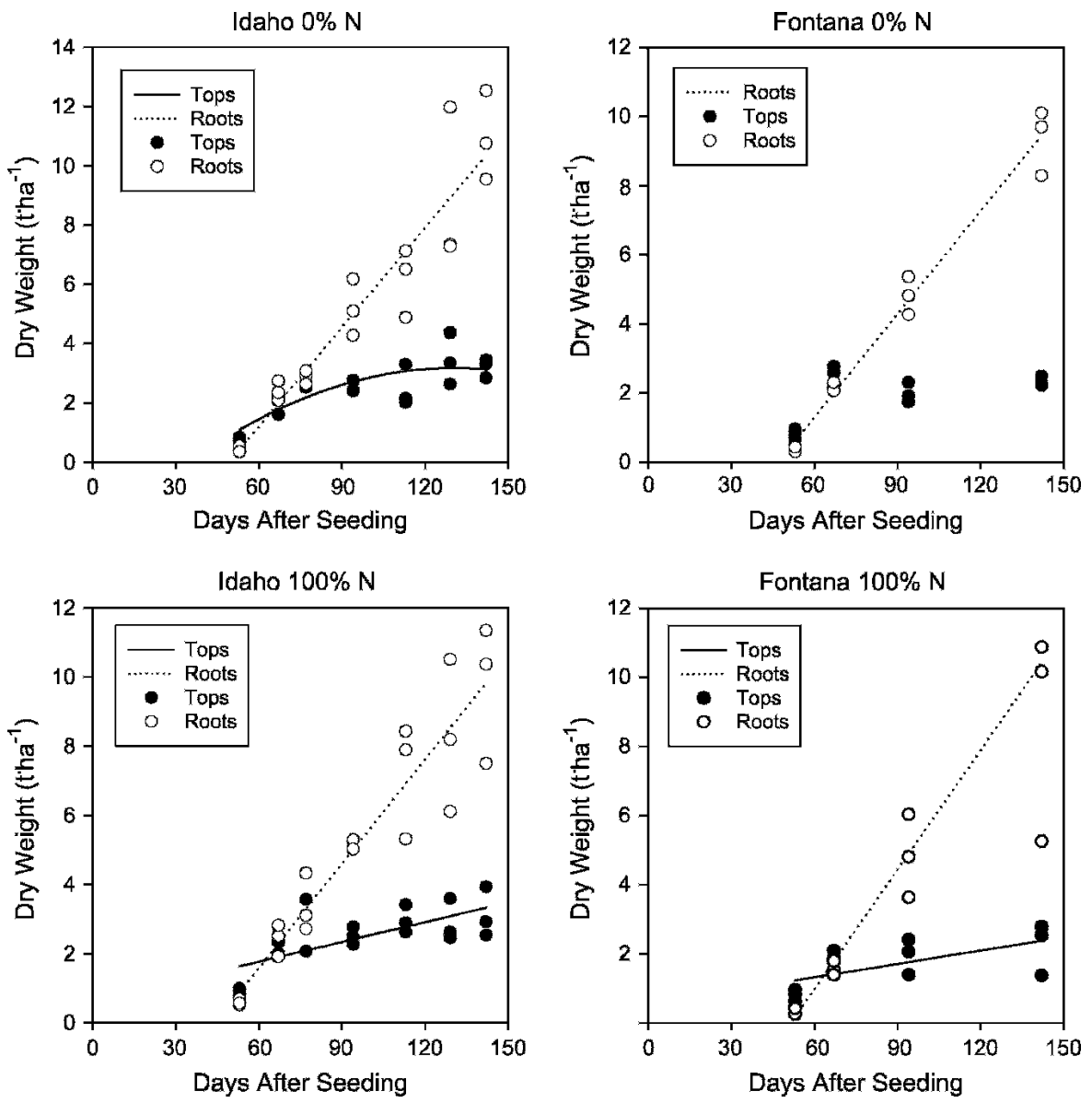

Fig. 1. Dry matter accumulation during the growing season for foliage and storage roots of 'Idaho' and 'Fontana' carrots grown on organic soil in 2003. Equations: $0 \% \mathrm{~N}$ Idaho foliage: $P<0.0001 \mathrm{R}^{2}=0.65 \mathrm{Y}=$ $-2.7088+0.09002 \mathrm{X}-0.000344 \mathrm{X}^{2} ; 0 \% \mathrm{~N}$ Idaho roots: $P<0.0001 \mathrm{R}^{2}=0.90 \mathrm{Y}=-5.5095+0.1118 \mathrm{X}$; $0 \% \mathrm{~N}$ Fontana foliage: not significant; $0 \% \mathrm{~N}$ Fontana roots: $P<0.0001 \mathrm{R}^{2}=0.98 \mathrm{Y}=-4.6693+$ $0.09945 \mathrm{X} ; 100 \% \mathrm{~N}$ Idaho foliage: $P=0.0003 \mathrm{R}^{2}=0.51 \mathrm{Y}=0.6258+0.01903 \mathrm{X} ; 100 \% \mathrm{~N}$ Idaho roots: $P<0.0001 \mathrm{R}^{2}=0.88 \mathrm{Y}=-4.4447+0.10049 \mathrm{X} ; 100 \% \mathrm{~N}$ Fontana foliage: $P=0.0214 \mathrm{R}^{2}=0.43 \mathrm{Y}=$ $0.5483+0.01291 \mathrm{X} ; 100 \% \mathrm{~N}$ Fontana roots: $P<0.0001 \mathrm{R}^{2}=0.98 \mathrm{Y}=-5.9255+0.11511 \mathrm{X}$ 

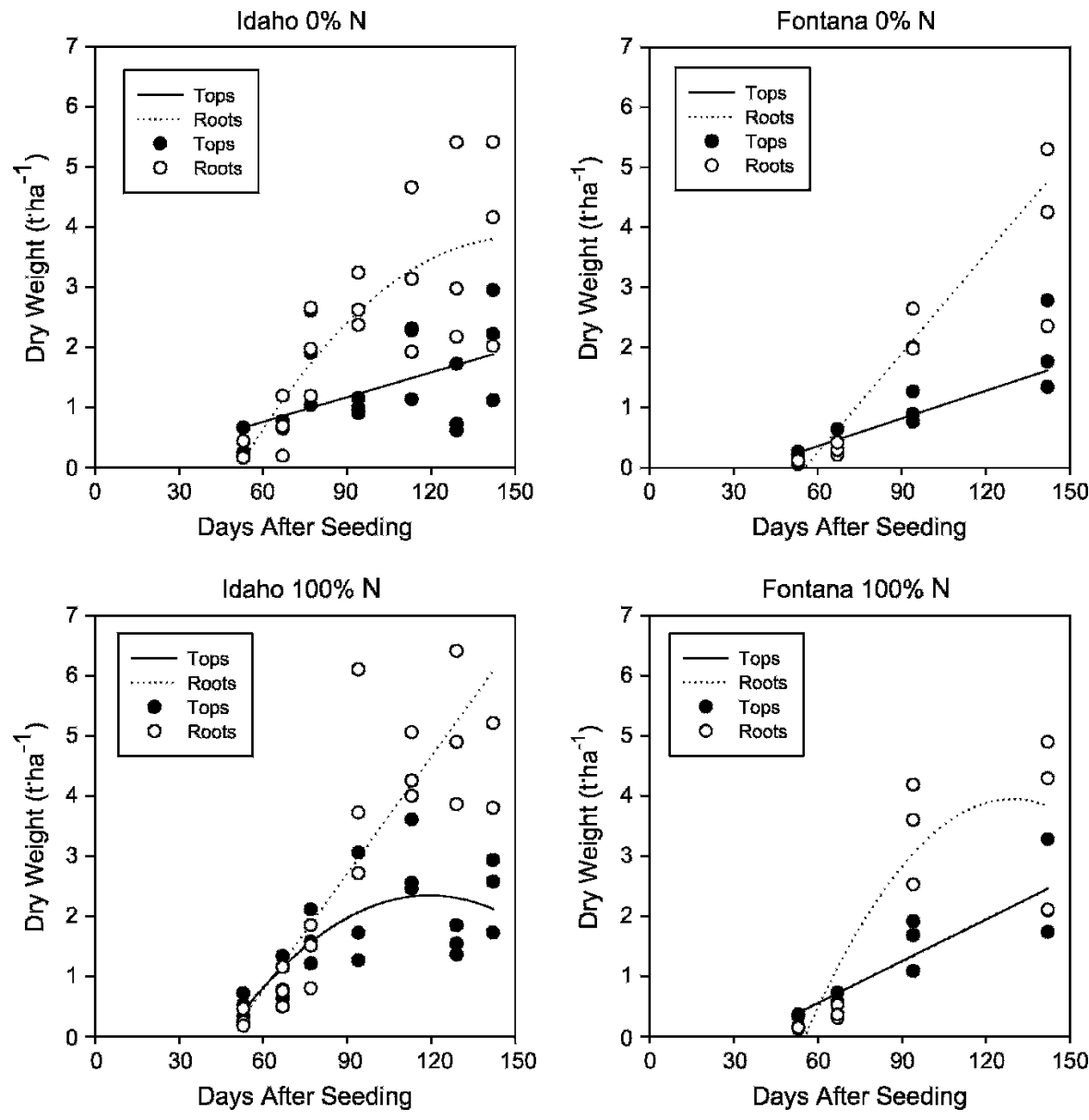

Fig. 2. Dry matter accumulation during the growing season for foliage and storage roots of 'Idaho' and 'Fontana' carrots grown on mineral soil in 2003. Equations: $0 \% \mathrm{~N}$ Idaho foliage: $P=0.0153 \mathrm{R}^{2}=0.27 \mathrm{Y}=$ $-0.06384+0.01372 \mathrm{X} ; 0 \% \mathrm{~N}$ Idaho roots: $P<0.0001 \mathrm{R}^{2}=0.66 \mathrm{Y}=-5.0585+0.1186 \mathrm{X}-0.0003965 \mathrm{X}^{2}$; $0 \%$ N Fontana foliage: $P<0.0001 \mathrm{R}^{2}=0.88 \mathrm{Y}=-0.5636+0.01536 \mathrm{X} ; 0 \% \mathrm{~N}$ Fontana roots: $P<0.0001$ $\mathrm{R}^{2}=0.96 \mathrm{Y}=-3.0522+0.05502 \mathrm{X} ; 100 \% \mathrm{~N}$ Idaho foliage: $P=0.0006 \mathrm{R}^{2}=0.56 \mathrm{Y}=-3.8775+$ $0.1044 \mathrm{X}-0.0004376 \mathrm{X}^{2} ; 100 \% \mathrm{~N}$ Idaho roots: $P<0.0001 \mathrm{R}^{2}=0.76 \mathrm{Y}=-3.1220+0.06479 \mathrm{X} ; 100 \%$ N Fontana foliage: $P<0.0001 \mathrm{R}^{2}=0.80 \mathrm{Y}=0.8425+0.02322 \mathrm{X} ; 100 \% \mathrm{~N}$ Fontana roots: $P=0.0009$ $\mathrm{R}^{2}=0.79 \mathrm{Y}=-8.1432+0.1868 \mathrm{X}-0.0007219 \mathrm{X}^{2}$.

Dry matter accumulation in the foliage was greater than in the roots by the first sampling date and increased gradually, leveled off, or declined slightly thereafter on both organic (Fig. 1) and mineral soil (Fig. 2). In cases in which DM in the foliage declined late in the season, the peak DM content occurred between 115 and 135 DAS. There were no consistent differences in the patterns of DM accumulation between the soil types, treatments, or cultivars, although 'Idaho' had slightly higher DM accumulation in the foliage than 'Fontana' in most cases.

Total $\mathrm{N}$ accumulation in the roots was similar to DM accumulation in all cases with a rapid linear increase beginning 53 DAS in 2003 (Fig. 3) and 66 DAS in 2004 for the organic soil and 53 DAS in 2003 (Fig. 4) and 67 DAS in 2004 for the mineral soil, regardless of the cultivar and $\mathrm{N}$ rates tested. However, the rate of increase in total $\mathrm{N}$ content in the roots did not decline near harvest in any case. In the foliage, a greater proportion of $\mathrm{N}$ accumulated before the first sampling date than DM in most cases (Figs. 3 and 4). In general, $\mathrm{N}$ accumulation in the roots increased more rapidly for 'Fontana' than for 'Idaho' on the organic soil, especially in 2004 (data not shown), but there were no major differences between the cultivars on the mineral soil (Fig. 4). Although there were no significant trends for $\mathrm{N}$ accumulation in the foliage in 12 of 16 cases, total $\mathrm{N}$ content appeared to level off or decline beyond 80 to 100 DAS in most cases. There was a more even distribution of $\mathrm{N}$ between the foliage and roots on the mineral soil (Fig. 4) compared with the organic soil (Fig. 3). More N accumulated and at a faster rate in the recommended $\mathrm{N}$ rate treatment compared with the no $\mathrm{N}$ treatment after the first sampling date on the mineral soil, especially in 2004 (data not shown), but there were no differences on the organic soil (Fig. 3). More $\mathrm{N}$ accumulated in the plants on the organic soil in both years than on the mineral soil. Nitrogen accumulation was almost double in 'Fontana' roots in 2004 as compared with 2003 on the organic soil without $\mathrm{N}$ application, but this did not occur on the mineral soil.

On the mineral soil in 2002, more $\mathrm{N}$ was applied than was removed in the harvested portion of the root at the recommended application rate (Table 1). A notable amount of $\mathrm{N}$ remained in the foliage at harvest. No attempt was made to quantify the $\mathrm{N}$ remaining in the fibrous roots at harvest, because the $\mathrm{N}$ contained in the fibrous roots would be quickly available to the next crop. The $\mathrm{N}$ content in 'Fontana' and 'Idaho' roots significantly increased with increasing $\mathrm{N}$ rate in 2003. In 2003, there was a positive net removal in the no $\mathrm{N}$ treatment and net removal declined as $\mathrm{N}$ rate increased. The trend in 2004 was similar to the 2003 results (Table 1). There were no major differences between the cultivars in any of the 3 years on the mineral soil (Table 1). Overall, $\mathrm{N}$ uptake and removal were low on the mineral soil, which was mainly the result of lower DM production and less available water $(42 \%, 65 \%$, and $36 \%$ of normal for Aug./Sept. 2002, June/ July 2003, and Sept./Oct. 2004, respectively).

On the organic soil, $\mathrm{N}$ uptake and removal were much higher than on the mineral soil (Table 2). Total $\mathrm{N}$ uptake in the shoot and storage root was up to $380 \mathrm{~kg} \cdot \mathrm{ha}^{-1}$ over the growing season. This resulted in a net removal of $\mathrm{N}$ at all $\mathrm{N}$ application rates in all years. Net removal was higher for 'Fontana' than for 'Idaho' in 2002 and 2004, but not in 2003. The highest net removal was 282 $\mathrm{kg} \cdot \mathrm{ha}^{-1} \mathrm{~N}$ at the no $\mathrm{N}$ application rate. Overall, $\mathrm{N}$ application rate did not affect the uptake of $\mathrm{N}$ or the accumulation in the foliage and roots (Table 2). Up to $80 \mathrm{~kg} \cdot \mathrm{ha}^{-1} \mathrm{~N}$ was returned to the soil in the foliage (Table 2).

Soil sampling, which is the focus of another study (Westerveld, 2005), revealed that total $\mathrm{N}$ and $\mathrm{NH}_{4}-\mathrm{N}$ concentrations were unchanged over the growing season and among $\mathrm{N}$ application rates in the top $30 \mathrm{~cm}$, whereas $\mathrm{NO}_{3}-\mathrm{N}$ concentrations increased in response to fertilizer application but were relatively constant over the season when no $\mathrm{N}$ was applied. Nitrate- $\mathrm{N}$ concentrations in the 30- to 90-cm depth in 2004 generally decreased over the growing season (Westerveld, 2005).

\section{Discussion}

This is the first work to examine $\mathrm{N}$ uptake in carrots over the growing season in relation to the distribution of this $\mathrm{N}$ between foliage and roots. Both DM and total $\mathrm{N}$ accumulation follow similar patterns. Dry matter and N content in the roots were low at 53 to 67 DAS, suggesting that there is only a small increase in both DM and $\mathrm{N}$ content in the roots until about 50 DAS. Between 50 and 60 DAS, the rate of DM and total $\mathrm{N}$ accumulation appears to accelerate $\left(40-140 \mathrm{~kg} \cdot \mathrm{ha}^{-1} / \mathrm{d}^{-1} \mathrm{DM} ; 0.4\right.$ $\left.3.3 \mathrm{~kg} \cdot \mathrm{ha}^{-1} / \mathrm{d}^{-1} \mathrm{~N}\right)$. The period of rapid increase was approximately 10 days earlier on average (50 DAS) in 2003 than in 2004. The air temperatures were higher in June and July 2003 than in 2004, and the plots were seeded 10 days later in 2003 on both soil types, at a time when air temperatures were warmer. Thus, it appears that air temperatures, or soil temperatures inferred by air temperatures, play an important role in determining the date of the initiation of storage root growth. 
Idaho $0 \% \mathrm{~N}$

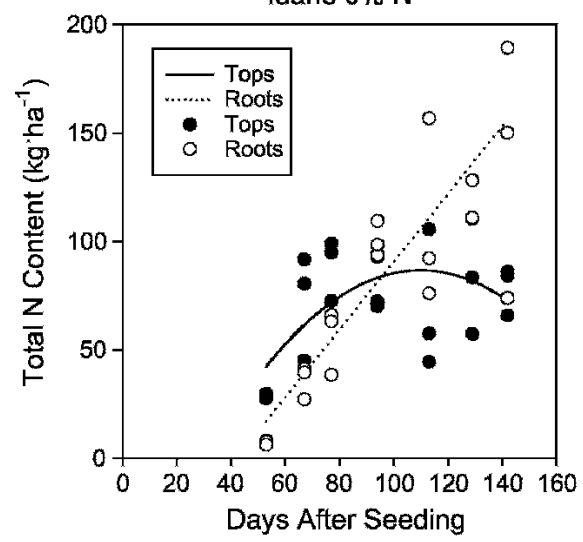

Idaho $100 \% \mathrm{~N}$

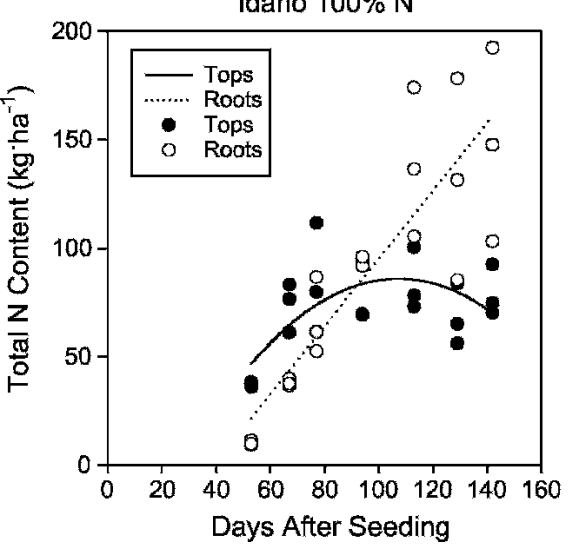

Fontana $0 \% \mathrm{~N}$


Fig. 3. Total $\mathrm{N}$ accumulation during the growing season for foliage and storage roots of 'Idaho' and 'Fontana' carrots grown on organic soil in 2003. Equations: $0 \% \mathrm{~N}$ Idaho foliage: $P=0.0260 \mathrm{R}^{2}=0.33 \mathrm{Y}=$ $-78.1461+2.9998 \mathrm{X}-0.01364 \mathrm{X}^{2} ; 0 \% \mathrm{~N}$ Idaho roots: $P<0.0001 \mathrm{R}^{2}=0.71 \mathrm{Y}=-65.684+1.5636 \mathrm{X} ; 0 \%$ N Fontana foliage: not significant; $0 \% \mathrm{~N}$ Fontana roots: $P<0.0001 \mathrm{R}^{2}=0.98 \mathrm{Y}=-84.4885+1.7334 \mathrm{X}$ (outlier removed); $100 \% \mathrm{~N}$ Idaho foliage: $P=0.0092 \mathrm{R}^{2}=0.41 \mathrm{Y}=-66.402+2.8390 \mathrm{X}-0.01323 \mathrm{X}^{2}$ $100 \% \mathrm{~N}$ Idaho roots: $P<0.0001 \mathrm{R}^{2}=0.77 \mathrm{Y}=-61.127+1.5626 \mathrm{X} ; 100 \% \mathrm{~N}$ Fontana foliage: not significant; $100 \% \mathrm{~N}$ Fontana roots: $P<0.0001 \mathrm{R}^{2}=0.99 \mathrm{Y}=-83.583+1.652 \mathrm{X}$ ( 2 outliers removed).

This is consistent with another study showing a rapid increase in carrot root fresh weight at 50 DAS (Rubatzky et al., 1999).

There could be physiological or morphologic triggers for this sudden increase in storage root growth. No defined growth stages for carrots have been identified (Strandberg, 2001). However, the initiation of the secondary cambium, which produces storage tissue, occurs at the time of true leaf emergence (Esau, 1940), which corresponds to 20 to 34 DAS based on greenhouse experiments (Hole et al., 1987a; Hole and Dearman, 1991). The delay between the initiation of the storage root and DM accumulation in this study could be the result of slower growth in the field compared with the greenhouse. It is also possible that the rapid increase in DM occurs much later than the initiation of the storage tissue. Hole et al. (1987b) showed that cell number increases exponentially between 34 and 55 DAS and then increases linearly thereafter. In addition, cell number is more closely related to root weight than cell size (Hole et al., 1987b). Furthermore, Hole et al. (1983) showed a rapid increase in both root and shoot DM between 50 and 75 DAS and suggested that storage root initiation occurs much earlier than growth curves suggest. Field studies in New York and New Zealand revealed a rapid increase in both root and shoot DM beginning at 60 to 68 DAS (Platenius, 1934; Reid and English, 2000). It is also possible that the increase in root DM accumulation is related to canopy closure. Increased competition among plants at this stage may trigger filling of the storage root. The rapid increase in storage root growth is not related to leaf area alone, because the dry weight of the leaves shows a much more gradual increase than storage root growth during this period.

Beyond 60 DAS, there was generally a rapid linear increase in both DM and total $\mathrm{N}$ content. Storage root growth was substantial late in the season, which is consistent with a study that demonstrated storage root DM content increases $28 \%$ to $41 \%$ during the last month before harvest (Evers, 1988). However, there were some cases in which root DM content leveled off near harvest. This could be the result of lower air temperatures, shorter photoperiod, and cloudier conditions before harvest at the end of October. It could also be the result of allocation of photoassimilates to the foliage because of regrowth that occurred after severe leaf blight damage.
Dry matter and $\mathrm{N}$ accumulation in the foliage were higher than in the storage root by the first assessment date and increased gradually beyond this point up to $100 \mathrm{DAS}$. The shape of the growth curves indicates that accumulation of DM and $\mathrm{N}$ in the foliage were more gradual in the current study than the rapid increase at 45 to 75 DAS shown in previous studies (Hole et al., 1983; Platenius, 1934; Reid and English, 2000; Rubatzky et al., 1999; Strandberg, 2001). The slight decline in both DM and total $\mathrm{N}$ content of the leaves that occurred beyond 100 DAS in the current study could be the result of leaf abscission or redistribution to the storage roots. A similar decline in foliage DM was also shown previously (Platenius, 1934). Regrowth of foliage could provide an explanation for the slight increase in DM and $\mathrm{N}$ content before harvest in the current study. The decrease beyond 100 DAS was more consistent for $\mathrm{N}$, which is similar to other root crops such as sugarbeet (Beta vulgaris L.) (Armstrong et al., 1986) and chicory (Cichorium intybus L.) (Améziane et al., 1997).

The current study shows that $\mathrm{N}$ accumulation in the foliage took priority over $\mathrm{N}$ accumulation in the storage root before 53 DAS and storage root $\mathrm{N}$ accumulation increased sharply beyond 53 DAS. An earlier study showed a more gradual increase in $\mathrm{N}$ uptake beginning at around 30 DAS and continuing at a linear rate until harvest (Salo, 1999). However, this more gradual uptake was on a whole plant basis. Combining the findings from both studies, it is likely that little $\mathrm{N}$ is taken up before 30 DAS and the majority of $\mathrm{N}$ taken up between 30 and 50 DAS is partitioned to the foliage. Most of the $\mathrm{N}$ uptake over the growing season occurs after $50 \mathrm{DAS}$ and is partitioned to the storage root.

There were no differences in the patterns of $\mathrm{N}$ uptake or distribution in the foliage and roots between the $2 \mathrm{~N}$ rates on either soil type. Consequently, there is no evidence to suggest that carrots distribute more $\mathrm{N}$ or DM to the storage root when $\mathrm{N}$ availability is reduced. The 2 cultivars also showed similar patterns of $\mathrm{N}$ and DM accumulation, which is similar to previous research (Hole et al., 1983; Hole et al., 1987a).

Total yield results for these plots, which are the focus of another study (Westerveld et al., 2006), showed there was no effect of $\mathrm{N}$ application rate on total yield of carrots on the organic soil in all 3 years and the mineral soil in 2002 (data not shown). Maximal total yield occurred at $200 \%$ and $91 \%$ of the recommended rate for 2003 and 2004 on the mineral soil, respectively. The minimal effect of $\mathrm{N}$ application on yield of carrots in this study is similar to previous reports in temperate regions (Sanderson and Ivany, 1997; Warncke, 1996; Westerveld, 2002). However, leaf blight damage is decreased as $\mathrm{N}$ application rate increases (Westerveld, 2005). Consequently, a greater understanding of $\mathrm{N}$ uptake and partitioning throughout the season is a required step in the development of improved $\mathrm{N}$ fertilization practices. 
Idaho $0 \% \mathrm{~N}$

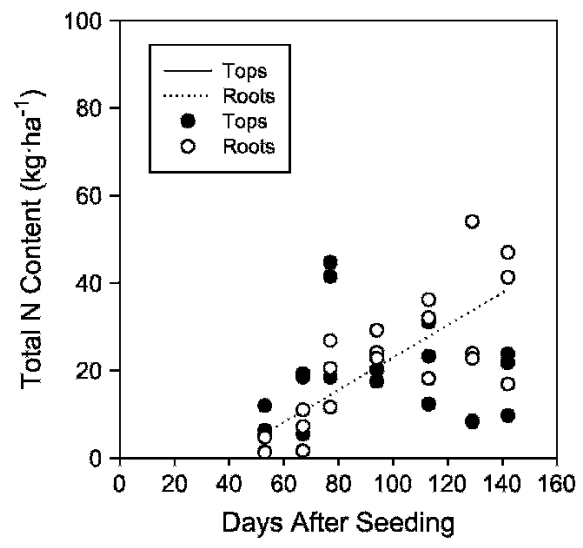

Idaho $100 \% \mathrm{~N}$



Fontana $0 \% \mathrm{~N}$


Fig. 4. Total $\mathrm{N}$ accumulation during the growing season for foliage and storage roots of 'Idaho' and 'Fontana' carrots grown on mineral soil in 2003. Equations: $0 \% \mathrm{~N}$ Idaho foliage: not significant; $0 \%$ N Idaho roots: $P<0.0001 \mathrm{R}^{2}=0.60 \mathrm{Y}=-14.062+0.3701 \mathrm{X} ; 0 \% \mathrm{~N}$ Fontana foliage: $P=0.0019 \mathrm{R}^{2}=$ $0.64 \mathrm{Y}=-0.2532+0.1502 \mathrm{X} ; 0 \% \mathrm{~N}$ Fontana roots: $P<0.0001 \mathrm{R}^{2}=0.99 \mathrm{Y}=-12.014+0.1450 \mathrm{X}+$ $0.001545 \mathrm{X}^{2}$ (outlier removed); $100 \% \mathrm{~N}$ Idaho foliage: not significant (outlier removed); $100 \% \mathrm{~N}$ Idaho roots: $P<0.0001 \mathrm{R}^{2}=0.62 \mathrm{Y}=-34.258+0.7374 \mathrm{X}$ (data does not follow a normal distribution); $100 \%$ N Fontana foliage: $P=0.0048 \mathrm{R}^{2}=0.69 \mathrm{Y}=-60.423+1.6976 \mathrm{X}-0.003747 \mathrm{X}^{2} ; 100 \% \mathrm{~N}$ Fontana roots: $P=0.0002 \mathrm{R}^{2}=0.76 \mathrm{Y}=-23.421+0.5103 \mathrm{X}$.

Less $\mathrm{N}$ was taken up by the crop and removed in the harvested portion on the mineral soil compared with the organic soil. There was a net addition of $\mathrm{N}$ to the mineral soil when $\mathrm{N}$ application was required for optimal yield. This $\mathrm{N}$ could then be lost by leaching. Similar results were also shown for mineral soil in Michigan (Warncke, 1996). Net $\mathrm{N}$ removal of 72 to $81 \mathrm{~kg} \cdot \mathrm{ha}^{-1}$ can be estimated for carrots that received no applied
$\mathrm{N}$. This is based on the finding that yields were similar if no $\mathrm{N}$ or $110 \mathrm{~kg} \cdot \mathrm{ha}^{-1} \mathrm{~N}$ was applied (47.7 and $52.3 \mathrm{t} \cdot \mathrm{ha}^{-1}$, respectively) (Westerveld, 2005). This net removal is slightly less than previous reports in unfertilized plots (Salo, 1999; Warncke, 1996). It is important to note that rainfall was generally below normal and total $\mathrm{N}$ uptake and removal on mineral soil could have been substantially higher if adequate soil moisture was present throughout the growing season.

Overall, carrots have potential as an $\mathrm{N}$ catch crop for mineral soils when residual $\mathrm{N}$ levels are high or optimum irrigation is supplied. It is likely that carrots in rotation with a crop with a high $\mathrm{N}$ requirement such as cole crops could have optimum yields without $\mathrm{N}$ application. In this case, there could be a significant reduction in $\mathrm{N}$ losses by including carrots in the rotation, because cole crops require $\mathrm{N}$ application of up to $500 \mathrm{~kg} \cdot \mathrm{ha}^{-1}$ for maximum yield (Zebarth et al., 1991), do not capture $20 \%$ to $70 \%$ of the fertilizer $\mathrm{N}$ applied (Everaarts, 1993), and leave 100 to $200 \mathrm{~kg} \cdot \mathrm{ha}^{-1} \mathrm{~N}$ in crop residues at harvest (Everaarts, 1993).

On organic soil, there is high potential for carrots to be used as an $\mathrm{N}$ catch crop. No applied $\mathrm{N}$ was required for optimum yield in any of the years of the trial. In addition, $\mathrm{N}$ uptake was not influenced by $\mathrm{N}$ application rate. Consequently, in all 3 years and at all $\mathrm{N}$ application rates tested, a large net removal of $\mathrm{N}$ occurred. Growing carrots without applied $\mathrm{N}$ resulted in a net $\mathrm{N}$ removal of between 130 and $282 \mathrm{~kg} \cdot \mathrm{ha}^{-1} \mathrm{~N}$. Although there was sufficient $\mathrm{N}$ in all 3 years on the organic soil, 'Fontana' took up and removed much more N in 2004 than 'Idaho' carrots, but there were no differences in 2002 or 2003. This result suggests that 'Fontana' carrots are capable of taking up and accumulating much more $\mathrm{N}$ in the roots than is required for optimum growth. There were no differences in yield between the 2 cultivars on either soil (Westerveld et al., 2006).

Total $\mathrm{N}$ uptake by carrots was up to 380.3 $\mathrm{kg} \cdot \mathrm{ha}^{-1} \mathrm{~N}$ and averaged $250 \mathrm{~kg} \cdot \mathrm{ha}^{-1} \mathrm{~N}$ on the

Table 1. Nitrogen $(\mathrm{N})$ budget as affected by $\mathrm{N}$ application rate of 2 carrot cultivars grown on mineral soil.

\begin{tabular}{|c|c|c|c|c|c|c|c|}
\hline \multirow[b]{2}{*}{ Year } & \multirow[b]{2}{*}{$\mathrm{N} \operatorname{applied}^{\mathrm{z}}\left(\mathrm{kg} \cdot \mathrm{ha}^{-1}\right)$} & \multicolumn{2}{|c|}{$\mathrm{N}$ in foliage $\left(\mathrm{kg} \cdot \mathrm{ha}^{-1}\right)$} & \multicolumn{2}{|c|}{$\mathrm{N}$ in roots $\left(\mathrm{kg} \cdot \mathrm{ha}^{-1}\right)$} & \multicolumn{2}{|c|}{ Net $\mathrm{N}$ removal $^{\mathrm{y}}\left(\mathrm{kg} \cdot \mathrm{ha}^{-1}\right)$} \\
\hline & & $\overline{\text { Idaho }}$ & $\overline{\text { Fontana }}$ & Idaho & $\overline{\text { Fontana }}$ & Idaho & Fontana \\
\hline \multirow[t]{2}{*}{2003} & 8 & 18.4 & 19.4 & 35.0 & 34.7 & 27.0 & 26.7 \\
\hline & 228 & 60.3 & 26.8 & 135.5 & 70.7 & -92.5 & -157.3 \\
\hline \multirow[t]{3}{*}{ Significance } & $\mathrm{L}$ & NS & NS & * & * & * & $* * *$ \\
\hline & $\mathrm{Q}$ & NS & NS & NS & NS & NS & NS \\
\hline & $\mathrm{R}^{2}$ & - & - & 0.54 & 0.58 & 0.63 & 0.97 \\
\hline \multirow{3}{*}{2004} & 118 & 35.0 & 21.1 & 80.2 & 49.1 & -37.8 & -68.9 \\
\hline & 173 & 39.5 & 51.2 & 80.6 & 162.7 & -92.4 & -10.3 \\
\hline & 228 & 47.6 & 20.1 & 93.9 & 76.7 & -134.1 & -151.3 \\
\hline \multirow[t]{3}{*}{ Significance } & $\mathrm{L}$ & ** & NS & NS & NS & $* * *$ & ** \\
\hline & Q & NS & NS & NS & NS & NS & NS \\
\hline & $\mathrm{R}^{2}$ & 0.37 & - & - & - & 0.75 & 0.39 \\
\hline
\end{tabular}

${ }^{\mathrm{z}}$ Total of $\mathrm{N}$ applied as fertilizer or as nitrate- $\mathrm{N}$ in rainwater.

${ }^{\mathrm{y}} \mathrm{Net} \mathrm{N}$ removal $=\mathrm{N}$ in roots $-\mathrm{N}$ applied.

$\mathrm{NS}, *, * *, * * *$ Nonsignificant or significant at $\mathrm{P}=0.05,0.01$, and 0.001 respectively.

$\mathrm{L}=$ linear, $\mathrm{Q}=$ quadratic. 
Table 2. Nitrogen $(\mathrm{N})$ budget as affected by $\mathrm{N}$ application rate of 2 carrot cultivars grown on organic soil.

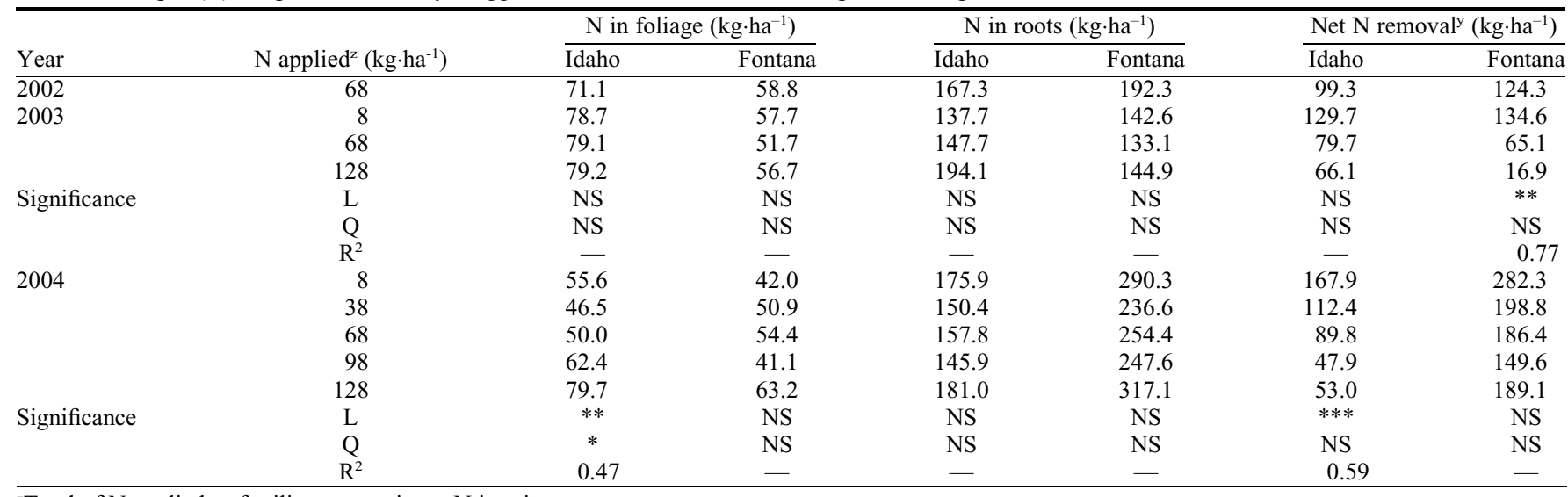

${ }^{z}$ Total of $\mathrm{N}$ applied as fertilizer or as nitrate- $\mathrm{N}$ in rainwater.

${ }^{\mathrm{y}} \mathrm{Net} \mathrm{N}$ removal $=\mathrm{N}$ in roots $-\mathrm{N}$ applied.

NS, *,***** Nonsignificant or significant at $\mathrm{P}=0.05,0.01$, and 0.001 respectively.

$\mathrm{L}=$ linear, $\mathrm{Q}=$ quadratic.

organic soil. This is higher than previous reported maximum of $214 \mathrm{~kg} \cdot \mathrm{ha}^{-1} \mathrm{~N}$ on organic soil in Quebec (Hamilton and Bernier, 1975) and also higher than mineral soils in Finland (150 kg.ha $\left.{ }^{-1} \mathrm{~N}\right)$ (Salo, 1999), Germany $\left(221-250 \mathrm{~kg} \cdot \mathrm{ha}^{-1} \mathrm{~N}\right.$ under very high fertilization)(Fink and Scharpf, 2000; Rühlmann and Geyer, 1993), and Michigan $\left(178 \mathrm{~kg} \cdot \mathrm{ha}^{-1} \mathrm{~N}\right)$ (Warncke, 1996). This $\mathrm{N}$ uptake is also similar to reported maximums for cabbage (Brassica oleracea var. capitata) (250-415 kg.ha $\left.{ }^{-1} \mathrm{~N}\right)$, broccoli (Brassica oleracea var. italica) (401 kg.ha $\left.{ }^{-1}\right)$, and cauliflower (Brassica oleracea var. botrytis) $\left(254 \mathrm{~kg} \cdot \mathrm{ha}^{-1}\right)$, which are crops known for their high $\mathrm{N}$ requirements and total $\mathrm{N}$ uptake over the season (Bakker, 2005; Fink and Scharpf, 2000; Salo, 1999; Westerveld, 2002). The source for the additional $\mathrm{N}$ must be mineralization of soil organic matter or $\mathrm{N}$ from deep in the soil profile. Because other crops grown on organic soil in this region such as onion (Allium cepa L.) (110 kg.ha ${ }^{-1}$ $\mathrm{N}$ ), celery (Apium graveolens var. dulce [Mill.] Pers.) (160 kg.ha $\left.{ }^{-1} \mathrm{~N}\right)$, and lettuce (Lactuca sativa L.) (89-96 kg.ha $\left.{ }^{-1} \mathrm{~N}\right)$ are not capable of the same level of $\mathrm{N}$ uptake (Fink and Scharpf, 2000; Hamilton and Bernier, 1975; Salo, 1999), it is likely that at least some of the $\mathrm{N}$ released by mineralization is not used by these crops. Consequently, carrots make an important contribution to crop rotation on organic soil, because they may reduce $\mathrm{N}$ losses substantially more than other crops grown at present.

Nitrogen remaining in the foliage at harvest ranged from a minimum of $15.2 \mathrm{~kg} \cdot \mathrm{ha}^{-1}$ on the mineral soil to a maximum of 79.7 $\mathrm{kg} \cdot \mathrm{ha}^{-1}$ on the organic soil. It is likely that a similar amount of $\mathrm{N}$ could be present in the fibrous root system, because the dry weight of the fibrous root system is similar to or exceeds that of the foliage (Westerveld, 2005). This $\mathrm{N}$ would be added back to the soil and part would be available to the next crop.

Carrots exhibited high NUE based on applied $\mathrm{N}$, because no $\mathrm{N}$ was required to produce maximum yield in 4 of 6 plots.
However, the large $\mathrm{N}$ uptake values for carrots, especially on the organic soil, suggest that carrots do not exhibit high NUE on an $\mathrm{N}$ uptake basis. Therefore, soil mineralized or residual $\mathrm{N}$ must supply the $\mathrm{N}$ requirements of the crop. When $\mathrm{N}$ was added to these plots, little additional $\mathrm{N}$ was taken up, suggesting that carrots have a low apparent $\mathrm{N}$ recovery. However, carrots can be used to increase the NUE of the entire crop rotation, because they can use the $\mathrm{N}$ remaining in the soil from a previous crop, reducing leaching while producing acceptable yield with no additional $\mathrm{N}$ application.

\section{Conclusions}

The patterns of $\mathrm{N}$ and DM accumulation in carrot roots and foliage during the growing season are consistent over cultivar, soil type, and $\mathrm{N}$ availability. Differences in air temperature among years alter the timing of the period of exponential increase in storage root growth and $\mathrm{N}$ accumulation. The majority of $\mathrm{N}$ uptake by the crop on an area basis occurs between 50 and 60 DAS (mid- to late July) and harvest. Carrots are capable of taking up and removing much more $\mathrm{N}$ than is applied on organic soil and can be used as an $\mathrm{N}$ catch crop to remove excess $\mathrm{N}$ from the soil and reduce losses. On mineral soil, there is potential for carrots to be used as an $\mathrm{N}$ catch crop if there is significant residual $\mathrm{N}$ from a previous crop. More $\mathrm{N}$ is required than is removed from the field when only low levels of $\mathrm{N}$ are available. On both soil types, $\mathrm{N}$ remaining in the foliage at harvest could be an important source of $\mathrm{N}$ to the next crop. Carrots exhibit high NUE based on $\mathrm{N}$ applied, because they produce maximal yield with minimal or no $\mathrm{N}$ application. However, carrots exhibit low NUE based on $\mathrm{N}$ uptake and $\mathrm{N}$ recovery, because a large amount of $\mathrm{N}$ uptake is required to maximize yield, and carrots recover little of the $\mathrm{N}$ that is applied during the current growing season. Because they are capable of extracting up to 330 $\mathrm{kg} \cdot \mathrm{ha}^{-1} \mathrm{~N}$ from the soil without added $\mathrm{N}$, carrots could be used to increase the NUE of the crop rotation.

\section{Literature Cited}

Améziane, R., C. Richard-Molard, E. Deléens, J.-F. Morot-Gaudry, and M.A. Limami. 1997. Nitrate $\left({ }^{15} \mathrm{NO}_{3}\right)$ limitation affects nitrogen partitioning between metabolic and storage sinks and nitrogen reserve accumulation in chicory (Cichorium intybus L.). Planta 202:303-312.

Armstrong, M.J., G.F.J. Milford, T.O. Pocock, P.J. Last, and W. Day. 1986. The dynamics of nitrogen uptake and its remobilization during the growth of sugar beet. J. Agr. Sci. 107:145154.

Bakker, C.J. 2005. Nitrogen management of broccoli (Brassica oleracea var. Italica). M.Sc. Thesis, Dept. of Plant Agriculture, University of Guelph, Guelph, Ont., Can.

Esau, K. 1940. Developmental anatomy of the fleshy storage organ of Daucus carota. Hilgardia 13:175-209.

Everaarts, A.P. 1993. General and quantitative aspects of nitrogen fertilizer use in the cultivation of brassica vegetables. Acta Hort. 339: 149-160.

Evers, A. 1988. Effects of different fertilization practices on the growth, yield and dry matter content of carrot. J. Agr. Sci. Finland 60:135152.

Fink, M. and H.C. Scharpf. 2000. Apparent nitrogen mineralization and recovery of nitrogen supply in field trials with vegetable crops. J. Hort. Sci. Biotechnol. 75:723-726.

Fream, W. 1905. Elements of Agriculture. 7th ed. The Royal Agricultural Society of England, London.

Hamilton, H.A. and R. Bernier. 1975. N-P-K fertilizer effects on yield, composition and residues of lettuce, celery, carrot and onion grown on an organic soil in Quebec. Can. J. Plant Sci. 55:453-461.

Hole, C.C., A. Barnes, T.H. Thomas, P.A. Scott, and W.E.F. Rankin. 1983. Dry matter distribution between the shoot and storage root of carrot (Daucus carota L.). Ann. Bot. (Lond.) 51:175-187.

Hole, C.C. and J. Dearman. 1991. Carbon economy of carrots during initiation of the storage root in cultivars contrasting in shoot:root ratio at maturity. Ann. Bot. (Lond.) 68:427-434. 
Hole, C.C., G.E.L. Morris, and A.S. Cowper. 1987a. Distribution of dry matter between shoot and storage root of field-grown carrots. II. Relationship between initiation of leaves and storage roots in different cultivars. J. Hort. Sci. 62:343-349.

Hole, C.C., G.E.L. Morris, and A.S. Cowper 1987b. Distribution of dry matter between shoot and storage root of field-grown carrots. III. development of phloem and xylem parenchyma and cell numbers in the storage root. J. Hort. Sci. 62:351-358.

Lund, R.E. 1975. Tables for an approximate test for outliers in linear models. Technometrics 17:473-476.

Ontario Ministry of Agriculture and Food. 2002. Vegetable production recommendations. Publication 363, Queen's Printer for Ontario, Toronto.

Platenius, H. 1934. Chemical changes in carrots during growth. Plant Physiol. 9:671-680.

Reid, J.B. and J.M. English. 2000. Potential yield in carrots (Daucus carota L.): Theory, test, and an application. Ann. Bot. (Lond.) 85:593605 .

Rubatzky, V.E., C.F. Quiros, and P.W. Simon. 1999. Carrots and related vegetable Umbelliferae. CABI Publishing, New York.
Rühlmann, J. and B. Geyer. 1993. Validation of a simulation model for carbon and nitrogen dynamics in soil in a field trial. Acta Hort. 339:75-84.

Ryan, M.C., R.G. Kachanoski, and R.W. Gillham. 2000. Overwinter soil nitrogen dynamics in seasonally frozen soils. Can. J. Soil Sci. 80:541-550.

Sanderson, K.R. and J.A. Ivany. 1997. Carrot yield response to nitrogen rate. J. Production Agr. 10:336-339.

Salo, T. 1999. N uptake by cabbage, carrot and onion. pp. 57-59. Agrifood Quality II: Quality Management of Fruits and Vegetables. Royal Society of Chemistry, Cambridge.

Shepers, J.S., D.D. Francais, and M.T. Thompson 1989. Automated total nitrogen of soil and plant samples. Commun. Soil Sci. Plant Anal. 20:949-959.

Sheppard, S.C. and T.E. Bates. 1986. Changes in nitrate concentration over winter in three southern Ontario soil profiles. Can. J. Soil Sci. 66: 537-541.

Strandberg, J.O. 2001. Monitoring growth and development of carrot on organic soils in Florida. Proc. Fla. State Hort. Soc. 114:307312 .
Thorup-Kristensen, K. and R. van den Boogaard. 1999. Vertical and horizontal development of the root system of carrots following green manure. Plant Soil 212:145-153.

Warncke, D.D. 1996. Soil and plant tissue testing for nitrogen management in carrots. Commun. Soil Sci. Plant Anal. 27:597-605.

Westerveld, S.M. 2002. Nitrogen management of cabbage, onions, and carrots as part of an integrated crop management program in Ontario. M.Sc. Thesis, Dept. of Plant Agriculture, Univ. of Guelph, Guelph, Ont, Can.

Westerveld, S.M. 2005. Nitrogen dynamics of the carrot crop and influences on yield and Alternaria and Cercospora leaf blights. Ph.D. Thesis, Dept. of Plant Agriculture, Univ. of Guelph, Guelph, Ont., Can.

Westerveld, S.M., M.R. McDonald, and A.W McKeown. 2006. Carrot yield, quality, and storability in relation to preplant and residual nitrogen on mineral and organic soils. Horttechnology 16:286-293.

Zebarth, B.J., S. Freyman, and C.G. Kowalenko. 1991. Influence of nitrogen fertilization on cabbage yield, head nitrogen content and extractable soil inorganic nitrogen at harvest. Can. J. Plant Sci. 71:1275-1280. 